This is an electronic reprint of the original article. This reprint may differ from the original in pagination and typographic detail.

Author(s): Haapanen, Mika; Ritsilä, Jari

Title: $\quad$ Can Migration Decisions Be Affected by Income Policy Interventions? Evidence from Finland

Year: $\quad 2007$

Version:

Please cite the original version:

Haapanen, M., \& Ritsilä, J. (2007). Can Migration Decisions Be Affected by Income Policy Interventions? Evidence from Finland. Regional Studies, 41(3), 339-348. https://doi.org/10.1080/00343400701282087

All material supplied via JYX is protected by copyright and other intellectual property rights, and duplication or sale of all or part of any of the repository collections is not permitted, except that material may be duplicated by you for your research use or educational purposes in electronic or print form. You must obtain permission for any other use. Electronic or print copies may not be offered, whether for sale or otherwise to anyone who is not an authorised user. 
Last updated: 29th March 2006

\title{
Can Migration Decisions Be Affected by Income Policy Interventions? Evidence from Finland*
}

\author{
MIKA HAAPANEN and JARI RITSILÄ
}

School of Business and Economics, PO Box 35, FI-40014 University of Jyväskylä, Finland.Emails: mika.p.haapanen@jyu.fi; jari.j.ritsila@jyu.fi

\begin{abstract}
Using Finnish micro-level data, this paper maps out whether migration decisions can be affected by income policy interventions. The analysis focuses on individuals living in peripheral regions and it distinguishes peripheral migration from growth-centre migration. In support of the human capital hypothesis, the estimation results imply that migration decisions can be affected by income policy interventions. For example, an intervention that would increase an individual's expected disposable income by $10 \%$, given that s/he does not move to a growth-centre region, would decrease his/her probability of growth-centre migration by approximately $12 \%$. However, the impact appears to be modest compared, for example, to the impact of education on migration.
\end{abstract}

Key words: Migration, Income, Policy interventions, Choice of destination JEL classification: R23, H21, C35

\footnotetext{
* Published as: Haapanen, M. \& Ritsilä, J. (2007) "Can migration decisions be affected by income policy interventions? Evidence from Finland", Regional Studies 41 (3), 339-348.
} 


\section{INTRODUCTION}

In recent years the direction of migration has been towards centres of population growth in Finland (PeKKala, 2000; HaApanen, 2003). ${ }^{1}$ At the same time, peripheral regions have lost a significant proportion of their human capital, as the young and educated move after better jobs and a more versatile cultural environment (RITSILÄ, 2001; RitsilÄ and HAAPANEN, 2003). If this phenomenon continues, it will lead unavoidably to the concentration of human capital in just a few regions. The Norwegian experiments applying differentiated taxation schedules (HANELL et al., 2002) has given rise to public debate on the role of income policies in Finnish regional policy. However, individually focused regional policy measures have not been applied in Finland so far.

This study contributes to this regional policy debate by mapping out whether migration decisions can be affected by income policy interventions in the first place. The analysis is based on Finnish micro-data for 1993-95, and it focuses on individuals living in peripheral regions. It is assumed in this paper that income policy interventions operate through changes in individuals' disposable income. Accordingly, the effect of expected disposable income on the migration decision is modelled. ${ }^{2}$ Empirical estimations are based on a random parameters logit model, which allows us to distinguish the determinants of peripheral migration from the determinants of growth-centre migration. Policy implications are discussed by means of an example illustrating the effects of changes in individuals' expected disposable income on the likelihood of migration. 


\section{A THEORETICAL FRAMEWORK}

Assume a country is divided into two regions, namely growth-centre and peripheral regions. In this analysis, only the migration decisions of individuals living in the peripheral regions are considered. It is logical, therefore, to assume that an individual $i$ may choose among three migration alternatives $(j=0,1,2)$. S/he may:

- $\quad$ stay in the current peripheral region $(j=0)$,

- $\quad$ migrate to another peripheral region $(j=1)$, or

- $\quad$ migrate to a growth-centre region $(j=2)$.

Following the human capital framework (SJAASTAD, 1962), it is assumed that migration decisions are based on an evaluation of the costs and benefits associated with each alternative. Let the present value of expected (lifetime) disposable income, $W_{i j}$, represent the benefits associated with alternative $j$, and we obtain

$$
W_{i j}=f\left(w_{i j}, r, \underline{\tau}_{i j}\right)
$$

where $w_{i j}$ is gross income, $r$ is the discount factor and $\underline{\tau}_{i j}$ is a vector of taxes levied on gross income. In addition, let $C_{i j}$ denote the present value equivalent of the costs associated with alternative $j$, including the actual costs of moving as well as the psychological costs (for example, leaving family members, relatives and/or friends). Then, the rule underlying the migration decision is that an individual $i$ will compare present values of the three migration alternatives:

$$
\ln P V_{i j}=\ln \left(W_{i j}-C_{i j}\right), \quad j=0,1,2
$$

and choose the location where $\ln P V_{i j}$ is maximized. ${ }^{3}$ The present value is expressed in natural logarithmic form to take account the nonlinearity of income streams (see 
MiNCER, 1974).

Following IsLAM and CHOUDHURY, 1990, the present value can be expressed

$$
\ln P V_{i j}=\ln \left(W_{i j}-\theta_{i j} W_{i j}\right)=\ln \left(W_{i j}\left(1-\theta_{i j}\right)\right)=\ln W_{i j}+\ln \left(1-\theta_{i j}\right)
$$

where we have rescaled the costs, so that $C_{i j}=\theta_{i j} W_{i j}$. Then a first-order Taylor approximation $^{4}$ of $\ln \left(1-\theta_{i j}\right)$ allows us to rewrite the present value as:

$$
\ln P V_{i j} \approx \ln W_{i j}-\theta_{i j}
$$

From this equation we can see that an improvement in economic opportunities at the destination ( $\left.W_{i j}, j=1,2\right)$ increases the net gains from migration and thus raises the likelihood of migration. For example, if an individual expects, ceteris paribus, that his/her lifetime disposable income in a growth-centre region will increase, this factor will make him/her more likely to migrate there (a 'pull' factor). Similarly, an improvement in the individual's economic opportunities in his/her current region of residence $\left(W_{i 0}\right)$ decreases the net gains from and thus lowers incentives to move. The reverse results can easily be deduced for the costs of migration.

The specification of the empirical model can be then expressed as:

$$
V_{i j}=\left(\ln W_{i j}\right) \eta_{i}+\theta_{i j} \alpha_{j}+\xi_{i j}
$$

where $\ln W_{i j}$ is the natural logarithm of expected disposable income ${ }^{5}, \eta_{i}$ and $\alpha_{j}$ are estimated parameters, and $\xi_{i j}$ is an identically independently distributed (i.i.d.) Gumbel error term (TRAIN, 2003). $V_{i j}$ measures the net benefit (utility) obtained from alternative $j$. Now the decision rule for migration becomes: an individual $i$ will choose migration alternative $k$, if $V_{i k}=\max _{j}\left\{V_{i j}\right\}$. 
Estimation of the empirical model (4), however, involves difficulties that have to be addressed. Firstly, we need estimates of the returns to migration for all the alternatives, but for each individual the disposable income, $W_{i j}$, is observed only for the particular alternative chosen. For example, for stayers, the census data does not provide any direct measure of what an individual's disposable income would be, if s/he had migrated to another peripheral region or to a growth-centre region. Ordinary least squares (OLS) estimates from the three subsamples $(j=0,1$ and 2) will not necessarily result in unbiased estimates, because individuals sort themselves into the regions that suit them best. The subsamples may not be randomly selected from the full sample (the so called self-selection problem; see HECKMAN, 1979; LEE, 1983; TUNALI, 2000).

To obtain consistent estimates of $\ln W_{i j}$ for all the alternatives, income equations corrected for selection for the stayers, periphery migrants and growth-centre migrants are specified as (see LEE, 1983):

$$
\ln W_{i j}=X_{i} \beta_{j}+\left(\sigma_{j} \rho_{j}\right) \lambda_{i j}+v_{i j}, j=0,1,2
$$

where $\ln W_{i j}$ is observed disposable income; $X_{i}$ is a vector of personal characteristics, such as gender, age, education, experience, marital and employment status, and location-specific factors (cf. ISLAM and CHOUDHURY, 1990); $\beta_{j}$ is a vector of parameters; and $v_{i j}$ is an i.i.d. normal error term. Here, $\sigma_{j}$ and $\rho_{j}$ are parameters of the sample selection correction variables $\lambda_{i j}{ }^{6}$

Secondly, the census data do not provide any direct measure of the costs, $C_{i j}$, and therefore of the ratio $\theta_{i j}$. As in IsLAm and CHOUDHURY, 1990, the costs of alternative $j$ are assumed to be related to a vector $Z_{i}$ by 


$$
\theta_{i j}=Z_{i} \delta_{j}+\omega_{i j}
$$

where $\delta_{j}$ is a vector of fixed parameters, $\omega_{i j}$ is an i.i.d. normal error term, and the vector $Z_{i}$ contains personal, household and location-specific characteristics; these are discussed in more detail in the next section (see Table 1).

Equations (5) and (6) allow reformulating the migration model (4) as:

$$
V_{i j}=\left(\ln \hat{W}_{i j}\right) \eta_{i}+Z_{i} \gamma_{j}+\varepsilon_{i j}
$$

where $\ln \hat{W}_{i j}$ is the predicted value ${ }^{7}$ of $\ln W_{i j}, \quad \eta_{i}$ and $\gamma_{j} \equiv \delta_{j} \alpha_{j}$ are estimated parameters, and $\varepsilon_{i j}$ is an i.i.d. Gumbel error term. ${ }^{8}$

However, since expected disposable income $\left(\ln \hat{W}_{i j}\right)$ is predicted, this explanatory variable is likely to be measured with error. The measurement error problem can lead to inconsistent parameter estimates and contaminate standard errors (CAMERON and TRIVEDI, 2005, Ch. 26). Hence, instead of a standard multinomial logit model, which assumes fixed parameter estimates and is likely to lead to biased estimates, ${ }^{9}$ a random parameters logit model is used herein (see MCFADDEN and TRAIN, 2000). ${ }^{10}$ Namely, the parameter of expected disposable income, $\eta_{i}$, is assumed to be randomly distributed across individuals. Randomness in $\eta_{i}$ captures unobserved effects and ensures more efficient and accurate parameter estimates. In the empirical application below, the distribution of $\eta_{i}$ is specified as normal with mean and standard deviation estimated from the data.

Finally, after the estimation of parameters $\eta_{i}$ and $\gamma_{j}$, the model can be used in simulations that illustrate the effect of income policy interventions on the migration 
decisions. Here, we consider the effect of expected disposable income on the propensities of staying, periphery migration and growth-centre migration. The effect can be evaluated by changing the level of disposable income an individual can expect for each migration alternative: $\hat{W}_{i j}, j=0,1,2$. Since disposable income depends on the level of taxation, one way of implementing such an income policy intervention is to create tax exemptions that will change the individual's expected disposable income for each of the three alternatives (see equation 1).

\section{DATA AND VARIABLES}

The data set used in the empirical study is a one-percent random sample drawn from the Finnish Longitudinal Census File. The data set provides a variety of information on individuals and their spouses. The analysis focuses on individuals living in peripheral regions at the end of $1993 .^{11}$ In this study the peripheral regions constitute all the NUTS4 regions, except the nine growth-centre regions (Helsinki, Porvoo, Salo, Tampere, Turku, Vaasa, Jyväskylä, Kuopio and Oulu). ${ }^{12}$ The regional division forms the basis for the dependent variable (migration choice) of the empirical model. Namely, an individual is classified as:

- $\quad$ a growth-centre migrant, if s/he moves in 1994 and his/her destination is one of the growth-centre regions,

- $\quad$ a periphery migrant, if s/he moves in 1994 and his/her destination is one of the peripheral regions, and

- $\quad$ a stayer, if no migration out of his/her region of residence takes place in 1994.

Table 1 presents the basic statistics with respect to the explanatory variables used in our empirical model. Only individuals aged between 16 and 60 with a positive annual 
income in 1995 were included in the working sample. ${ }^{13}$ After imposing these restrictions and omitting observations with missing information, we were left with 9,221 individuals. Of these, 8,948 individuals (97.0\%) remained in their region of origin, 127 individuals (1.4\%) moved to the peripheral regions and 146 individuals (1.6\%) moved to growth-centre regions in 1994.

\section{TABLE 1 AROUND HERE}

In order to obtain expected disposable income for 1995, three income equations were estimated (see eq. (5) above). Because the income parameters are not the focus of this

paper, the estimation results are presented in the Appendix. The parameters are merely used to compute expected disposable income for each individual for each of the three migration alternatives (see bottom of Table 1 for mean values).

Alongside expected income, a variety of other factors controlling for the costs and benefits of migration are included in the model. The propensity to move is likely to diminish with age and increase with the individual's level of education (SJAASTAD, 1962; Antolin and Bover 1997; RitsilÄ and OvaskAinen, 2001; Ritsilë and HAAPANEN, 2003). Marital status, spouse's employment and presence of children may indicate the existence of additional local household ties, as well as affecting the direct costs of moving (MinCER, 1978; Nivalainen, 2004). Previous studies also clearly show that home-owners have a low propensity to move (HENLEY, 1998; TERVO, 2000; RITSILÄ and OVASKAINEN, 2001).

Personal unemployment and high regional unemployment may encourage migration (Pissarides and Wadsworth, 1989; Kauhanen and Tervo, 2002). Correspondingly, migration propensity is likely to decrease with work experience. A negative association is expected between initial earnings and migration: the lower the earnings, the 
lower the opportunity costs of moving, although, the evidence from previous empirical studies is not conclusive (see Tervo, 2000; Ritsilä and Ovaskainen, 2001; Nivalainen, 2004). A high level of taxation in the region of origin in turn may be an incentive to move. ${ }^{14}$ Commuting is also likely to increase the likelihood of migration (Romani et al., 2003; NivAlainen, 2004). ${ }^{15}$

The characteristics of the region of origin play a crucial role in migration decisions (Axelsson and Westerlund, 1998; KnAPP et al., 2001). The further away on the periphery an individual lives, the further away s/he is from the wider range of services and employment opportunities of the growth centres. Thus, migration propensity is expected to increase with the distance to the closest growth-centre region. A high proportion of service workers reflects local amenities and is likely to discourage migration (cf. NiVALAINEN, 2004). Finally, individuals living in their region of birth are expected to move less because of attachment to the region.

\section{ESTIMATION RESULTS}

Table 2 presents the estimation results of the migration model. Maximum likelihood estimates of the parameters are given together with their asymptotic standard errors and significance levels. The parameters for the periphery and growth-centre migration alternatives serve as a basis for identifying differences in migration behaviour. Deviations in parameter values imply differences in the weight of particular variables in the migration decision between periphery and growth-centre.

\section{TABLE 2 AROUND HERE}




\section{Personal characteristics}

As expected, the results show that the likelihood of migration diminishes with age. Interestingly, the much larger negative estimate for growth-centre migration implies that older people are less likely to move to the growth-centre regions than to the periphery. In accordance with RITSILÄ and HAAPANEN, 2003, the likelihood of growth-centre migration increases with the individual's level of education. However, this is not true of migration to the peripheral regions. Combining the effects of age and education, it can be deduced that the peripheral regions are losing an important part of their human capital. Young and educated individuals move from the periphery to the growth-centres, and human capital becomes concentrated in a few regions (c.f. RITSILÄ and HAAPANEN, 2003). In addition, the demographical structure of the peripheral regions worsens still further.

\section{Household characteristics}

The impact of marital status on migration seems to be closely related to spouse's employment status, and thus to attachment to the local labour market. An employed spouse significantly reduces the likelihood of moving. On the contrary, a non-employed spouse may even increase the likelihood of moving, especially to a growth-centre region. Having school-aged children significantly discourages the likelihood of migration to a growth-centre. However, younger children do not have a significant impact on the likelihood of migration (see also NivalAinen, 2004). Home-owning status significantly reduces the likelihood of migration to the peripheral regions, but not to the growth-centre regions. As a whole, the results suggest that individuals in settled circumstances are less willing to migrate to a new location with less certain prospects. 


\section{Labour market characteristics}

The estimates imply that personal unemployment enhances the likelihood of moving to the periphery, but not to a growth-centre (cf. KAUHANEN and Tervo, 2002). The insignificant estimate obtained for regional unemployment is in line with previous findings (see, for example, HÄMÄLÄINEN, 2002. A person's work experience does not

explain the likelihood of migration to either a peripheral or growth-centre region. ${ }^{16}$ However, our findings indicate that the higher the individual's initial earnings, the less likely s/he is to move to another peripheral region. As expected, commuting significantly adds to the propensity to move. The effect is greater on growth-centre migration than peripheral migration. According to the results, it seems that unemployment does not induce migration to the growth-centres as strongly as has been assumed. Instead, commuting seems to be an important determinant in migration behaviour, especially in migration to growth-centres.

Characteristics of the region of origin

The likelihood of migration is significantly related to the distance to the closest growthcentre region. The further away from a growth-centre region an individual lives, the more likely s/he is to move. On the contrary, living in one's region of birth reduces the willingness to move. In addition, a higher share of service workers in the home region significantly deters migration to another peripheral region. In general, the availability of services is related to the distance of region from a growth-centre - the more distant the region, the fewer the services available. 


\section{Expected disposable income}

As discussed earlier, the impact of expected disposable income on the migration decision is estimated with a normally distributed random parameter. Table 2 shows that the mean value of the parameter density is significant at the 0.05 level. This provides evidence supporting the human capital hypothesis: migration decisions are affected by disposable income expectations. However, no significant random variation in the income expectations parameter is found, as indicated by the insignificance of the standard deviation. Triangular and uniform densities were also tried, but the results were very similar and are therefore not reported. To sum up, expected disposable income has an effect on migration behaviour, but a closer examination is needed to evaluate its policy implications.

\section{POLICY IMPLICATIONS}

Policy implications are next discussed with an example illustrating the effects of changes in individuals' expected disposable income on the likelihood of migration. Table 3 illustrates the estimated impacts and costs of two income policy interventions aimed at increasing disposable income in four northern subregions of Finland. The interventions would increase an individual's disposable income by $10 \%$ and $25 \%$, respectively, given that s/he does not move to a growth-centre region. In other words, the increase in income is conditional on the potential migrant staying put or moving to another peripheral region. ${ }^{17}$

At the top of Table 3 are the predicted probabilities for the three migration alternatives before and after the two interventions. They have been calculated as averages over all observations using the parameter estimates reported in Table 2. By comparing the statistics in the first two columns we can see that a $10 \%$ increase in expected 
disposable income would decrease the probability of growth-centre migration by approximately $12 \%$ (from 0.0159 to 0.0140 ). Similarly, the final column indicates that a $25 \%$ increase in expected disposable income would decrease the probability of growthcentre migration by approximately $26 \%$ (from 0.0159 to 0.0117 ). Hence, it seems that migration decisions can be affected by income policy interventions. However, the impact of expected disposable income on the propensity of migration remains modest compared, for example, to the impact of education.

\section{TABLE 3 AROUND HERE}

In considering the benefit of an intervention, its costs should also be taken into account (see bottom of Table 3). Naturally, the costs of the intervention will depend positively on the level of income and the number of persons affected by it. In order to make the example intervention policy feasible, it was only targeted at a restricted population in the four northernmost regions of Finland (Torniolaakso, and Tunturi-, Northern- and Eastern-Lapland). In 1999, these regions were home to 26,898 employed people with an

average annual disposable income of 9,137 euros. The income policy interventions, if implemented, would raise average annual disposable income to 10,051 and 11,421 euros, respectively. Thus, our rough estimate is that the interventions would have cost approximately 24 and 61 million euros. However, it should be noted that these estimates do not take changes in migration flows, and thus in the size of the working population in the target regions, into account. Note also that the costs would be lower, if the income policy intervention was targeted at younger individuals since, on average, they have lower earnings. 


\section{CONCLUDING REMARKS}

The results of the empirical analysis implied that substantial differences exist between the determinants of peripheral and growth-centre migration in Finland. The migration decision is closely linked to the potential migrant's personal, household and labour market characteristics as well as to the characteristics of his/her home region. Firstly, young and higher educated individuals tend to move from the periphery to the growthcentres. This means that the peripheral regions are losing an important proportion of their human capital, and that human capital is becoming concentrated in a few regions. Secondly, individuals in settled circumstances (families with children, home-owners) are less willing to migrate to a new location with less certain prospects. Thirdly, it seems that the unemployment does not induce migration to the growth-centres as strongly as has been assumed. Instead, commuting seems to be an important factor determining the migration behaviour, especially migration to growth-centres. Finally, the further away from a growth-centre region an individual lives, the more likely s/he is to move. On the contrary, a higher share of service workers significantly deters migration to another peripheral region.

In support of the human capital hypothesis, the estimation results implied that migration decisions are affected by disposable income expectations. Hence, it seems that migration decisions can be affected by income policy interventions. However, the impact of expected disposable income on the propensity to migrate turned out to be rather modest. In addition, the use of an income policy intervention is not unproblematic. Even if the intervention were only targeted at few peripheral regions, it would still be a rather expensive option. This is mainly due to the general nature of such an intervention, as it applies to all employed individuals regardless of their propensity to 
migrate. At the same time equality between individuals and between regions becomes an issue. Co-operation between regions may suffer as a result of inequalities of treatment between them. In addition, peripheral regions contain a large pool of unemployed inhabitants.

Acknowledgements - The authors gratefully acknowledge financial support from the Academy of Finland and Yrjö Jahnsson Foundation. The authors wish to thank Hannu Tervo, Kari Hämäläinen, Brigitte Waldorf, Arnaud Chevalier and two anonymous referees for their useful comments and suggestions on this paper.

\section{APPENDIX}

Constructing expected disposable income for 1995

An individual's disposable income in 1995 was calculated by subtracting state, municipal, Church, and social security taxes from earned annual income. Possible tax deductions were not taken into account in the calculations. Because we knew each individual's region of residence, but not municipality, we had to use a proxy for the municipal tax paid by each individual. It was calculated as a population-weighted average of all the municipal taxes in the region.

We then estimated three income equations (5). They did not show evidence of selfselection (Table A1): the null hypothesis of no self-selection could not be rejected at the 0.05 level with t-test values of $-1.478,1.353$ and -1.921 in the samples of stayers, periphery migrants and growth-centre migrants, respectively. Hence, we proceeded by estimating the income parameters with the standard ordinary least squares (OLS) method. Finally, these parameters were used to compute expected disposable income for each individual for each of the three migration alternatives. 
Table A1. Ordinary least squares estimates of the disposable income equations

\begin{tabular}{lcccccc}
\hline \multirow{2}{*}{ Variable } & \multicolumn{5}{c}{ Sample in the estimation of disposable income equation } \\
\cline { 2 - 7 } Constant & \multicolumn{3}{c}{ Stayers } & Periphery migrants & Growth-centre migrants \\
Sex (male = 1) & $0.901^{* *}$ & $(0.093)$ & 1.191 & $(0.791)$ & 0.414 & $(0.934)$ \\
Age & $0.226^{* *}$ & $(0.013)$ & 0.167 & $(0.120)$ & 0.065 & $(0.124)$ \\
Age squared & $0.249^{* *}$ & $(0.054)$ & -0.086 & $(0.525)$ & 0.948 & $(0.615)$ \\
Lower secondary education & $-0.031^{* *}$ & $(0.007)$ & 0.016 & $(0.074)$ & -0.123 & $(0.083)$ \\
Upper secondary education & $0.092^{* *}$ & $(0.016)$ & 0.304 & $(0.162)$ & -0.354 & $(0.234)$ \\
Lower upper education & $0.225^{* *}$ & $(0.019)$ & $0.657^{* *}$ & $(0.166)$ & 0.184 & $(0.209)$ \\
Higher upper education & $0.454^{* *}$ & $(0.026)$ & $0.879 * *$ & $(0.196)$ & 0.309 & $(0.251)$ \\
Married or cohabiting & $0.727^{* *}$ & $(0.034)$ & $1.258^{* *}$ & $(0.261)$ & 0.417 & $(0.273)$ \\
\# children under age 7 & $0.083^{* *}$ & $(0.018)$ & -0.258 & $(0.136)$ & -0.156 & $(0.142)$ \\
Unemployed & $-0.087^{* *}$ & $(0.011)$ & 0.057 & $(0.095)$ & -0.208 & $(0.120)$ \\
Employed & $-0.171^{* *}$ & $(0.031)$ & -0.316 & $(0.182)$ & -0.057 & $(0.185)$ \\
Work experience & $0.387^{* *}$ & $(0.030)$ & -0.272 & $(0.184)$ & 0.255 & $(0.179)$ \\
Work experience squared & -0.022 & $(0.012)$ & 0.137 & $(0.097)$ & 0.005 & $(0.110)$ \\
Distance to closest growth-centre & $0.008^{* *}$ & $(0.001)$ & 0.001 & $(0.010)$ & 0.002 & $(0.012)$ \\
\hline R & $-0.003^{* *}$ & $(0.001)$ & 0.000 & $(0.008)$ & -0.012 & $(0.008)$ \\
t-test for self-selection & \multicolumn{2}{c}{0.308} & & 0.422 & 1.353 & 0.267 \\
Number of observations & -1.478 & & 127 & -1.921 \\
\hline
\end{tabular}

Notes: Dependent variable: $\ln ($ disposable income in 1995). First, the estimated parameter is given, followed by the standard errors in brackets. All variables measured at the region of origin in 1993; see Table $1 .^{*}(* *)=$ statistically significant at the $0.05(0.01)$ level. 


\section{REFERENCES}

ANTOLIN P. and Bover O. (1997) Regional migration in Spain: the effect of personal characteristics and of unemployment, wage and house price using pooled crosssections, Oxford Bulletin of Economics and Statistics 59, 215-235.

AxELSSON R. and Westerlund O. (1998) A panel study of migration, household real earnings and self-selection, Journal of Population Economics 11, 113-126.

Cameron A. C. and Trivedi P. K. (2005) Microeconometrics: Methods and Applications. Cambridge University Press, New York.

Carroll, R. J., Ruppert, D. and Stefanski, L. A. (1995) Measurement Error in Nonlinear Models. Chapman \& Hall, London.

ChARney A. H. (1993) Migration and the public sector: a survey, Regional Studies 27, 313-326.

ELIASSON K., LiNDGREN U. and WeSTERLUND O. (2003) Geographical labour mobility: migration or commuting? Regional Studies 37, 827-837.

FALARIS E. M. (1987) A nested logit migration model with selectivity, International Economic Review 28, 429-443.

HAAPANEN M. (2003) Studies on the determinants of migration and the spatial concentration of labour, Jyväskylä Studies in Business and Economics, No. 27, University of Jyväskylä, Jyväskylä.

Hanell T., Aalbu H. and Neubauer J. (2002) Regional development in the Nordic countries 2002, Nordregio Report 2002:2, Nordregio, Stockholm.

Heckman J. (1979) Sample selection bias as a specification error, Econometrica 47, 153-161. 
HENLEy A. (1998) Residential mobility, housing equity and the labour market, The Economic Journal 108, 414-427.

HÄMÄLÄINEN K. (2002) Unemployment, selective employment measures and interregional mobility of labour, Papers in Regional Science 81, 423-441.

IsLAM M. N. (1989) Tiebout hypothesis and migration-impact of local fiscal policies, Public Finance 44, 406-418.

IsLAM M. N. and CHOUdHURY S. A. (1990) Self-selection and intermunicipal migration in Canada, Regional Science \& Urban Economics 20, 459-472.

Kauhanen M. and Tervo H. (2002) Who moves to depressed regions? An analysis of migration streams in Finland in the 1990s, International Regional Science Review 25, 200-218.

Knapp T., White N. and Clark D. (2001) A nested logit approach to household mobility, Journal of Regional Science 41, 1-22.

LEE L.-F. (1983) Generalized econometric models with selectivity, Econometrica 51, $507-512$.

LUCAS R. E. (1997) Internal migration in developing countries, in ROSENZWEIG M. R. and StARK O. (Eds) Handbook of Population and Family Economics, Vol. 1B, pp. 721-798. Elsevier, Amsterdam.

McFadDEn D. and Train K. (2000) Mixed MNL models for discrete response, Journal of Applied Econometrics 15, 447-476.

MinCER J. (1974) Schooling, Experience, and Earnings. NBER, Columbia University Press, New York.

Mincer J. (1978) Family migration decisions, Journal of Political Economy 86, 749773. 
Mood A., GraybiLl F. and Boes D. (1974) Introduction to the Theory of Statistics, 3rd edition. McGraw-Hill, New York.

Nivalainen S. (2004) Determinants of family migration: short moves vs. long moves, Journal of Population Economics 17, 157-175.

PEKKALA S. (2000) Regional convergence and migration in Finland 1960-95, Jyväskylä Studies in Business and Economics, No. 4, University of Jyväskylä, Jyväskylä.

PissARIDES C. A. and WADSWORTH J. (1989) Unemployment and the inter-regional mobility of labour, The Economic Journal 99, 739-755.

RITSILÄ J. (2001) Studies on spatial concentration of human capital, Jyväskylä Studies in Business and Economics, No. 7, University of Jyväskylä, Jyväskylä.

RitSILÄ J. and HAAPANEN M. (2003) Where do the highly educated migrate? Microlevel evidence from Finland, International Review of Applied Economics 17, 437448.

RITSILÄ J. and OvASKAINEN M. (2001) Migration and regional centralization of human capital, Applied Economics 33, 317-325.

ROMANí J., SURIÑACH J. and ARTís M. (2003) Are commuting and residential mobility decisions simultaneous? The case of Catalonia, Spain, Regional Studies 37, 813826.

SJAASTAD L. A. (1962) The costs and returns of human migration, Journal of Political Economy 70 (Supplement), 80-93.

STERN S. (1997) Simulation-based estimation, Journal of Economic Literature 35, 2006-2039.

TERvo H. (2000) Migration and labour market adjustment: empirical evidence from Finland 1985-90, International Review of Applied Economics 14, 343-360. 
Train K. (2003) Discrete Choice Methods with Simulation. Cambridge University Press, Cambridge.

TUNALi I. (2000) Rationality of migration, International Economic Review 41, 893-920.

UNiTED NATIONS (1999) World urbanization prospects: the 1999 revision, United Nations Population Division.

VIJVERBERG W. P. (1995) Dual selection criteria with multiple alternatives: migration, work status, and wages, International Economic Review 36, 159-185.

Westerlund O. and Wyzan M. L. (1995) Household migration and the local public sector: evidence from Sweden, 1981-1984, Regional Studies 29, 145-157.

WiLliamson J. G. (1988) Migration and urbanization, in CHENERY H. and SRINIVASAN T. N. (Eds) Handbook of Development Economics, Vol. 1, pp. 425-465. Elsevier, Amsterdam. 
Table 1. Definitions and descriptive statistics of the explanatory variables

\begin{tabular}{|c|c|c|c|}
\hline Variable & Scale & Definition & Mean \\
\hline Age & Continuous & Age in years divided by 10 & 3.805 \\
\hline $\begin{array}{l}\text { Lower secondary } \\
\text { education }\end{array}$ & $(0,1)$ & $1=$ lower secondary education; $0=$ otherwise & 0.377 \\
\hline $\begin{array}{l}\text { Upper secondary } \\
\text { education }\end{array}$ & $(0,1)$ & 1 = upper secondary education; 0 = otherwise & 0.202 \\
\hline Lower upper education & $(0,1)$ & 1 = lower upper education; 0 = otherwise & 0.089 \\
\hline Higher upper education & $(0,1)$ & 1 = higher upper education; $0=$ otherwise & 0.044 \\
\hline Married or cohabiting & $(0,1)$ & $1=$ married or cohabiting; $0=$ otherwise & 0.759 \\
\hline Spouse employed & $(0,1)$ & $\begin{array}{l}1 \text { = married or cohabiting and spouse's main } \\
\text { activity is employment during the last week of } \\
\text { 1993; } 0=\text { otherwise }\end{array}$ & 0.499 \\
\hline \# children under 7 & Continuous & Number of children under age 7 & 0.296 \\
\hline \# children aged 7-18 & Continuous & Number of children aged 7-18 & 0.556 \\
\hline Home-owner & $(0,1)$ & 1 = home-owner; 0 = otherwise & 0.565 \\
\hline Employed & $(0,1)$ & $\begin{array}{l}1=\text { main activity is employment during the last } \\
\text { week of 1993; } 0=\text { otherwise }\end{array}$ & 0.768 \\
\hline Unemployed & $(0,1)$ & $\begin{array}{l}1=\text { main activity is unemployment during the last } \\
\text { week of } 1993 ; 0=\text { otherwise }\end{array}$ & 0.163 \\
\hline Work experience & Continuous & $\begin{array}{l}\text { No. of months of employment during 1987-93 } \\
\text { divided by } 10\end{array}$ & 6.450 \\
\hline Initial earnings & Continuous & $\begin{array}{l}\text { Annual earnings in } 1993(10,000 \text { euro })=\text { annual } \\
\text { income from labour plus self-employment } \\
\text { income and work-related transfers, such as } \\
\text { unemployment insurance and sick pay. }\end{array}$ & 1.653 \\
\hline Commuting & $(0,1)$ & $\begin{array}{l}1=\text { commuting from the municipality in the last } \\
\text { week of } 1993 ; 0=\text { otherwise }\end{array}$ & 0.328 \\
\hline $\begin{array}{l}\text { Regional rate of } \\
\text { unemployment }\end{array}$ & Continuous & Regional rate of unemployment, \% & 23.824 \\
\hline Share of service workers & Continuous & Share of employed labour force in services & 6.817 \\
\hline Living in region of birth & $(0,1)$ & $1=$ living in region of birth; $0=$ otherwise & 0.574 \\
\hline $\begin{array}{l}\text { Distance to the closest } \\
\text { growth-centre }\end{array}$ & Continuous & $\begin{array}{l}\text { Individual's distance to the closest growth-centre } \\
\text { using distances by road (10 km) }\end{array}$ & 10.993 \\
\hline Municipal taxation & Continuous & $\begin{array}{l}\text { Population-weighted average of municipal taxes } \\
\text { in the region of origin }\end{array}$ & 17.662 \\
\hline $\begin{array}{l}\text { Ln(expected disposable } \\
\text { income) }\end{array}$ & Continuous & $\begin{array}{l}\text { Natural logarithm of predicted disposable income } \\
\text { for } 1995 \text { (1,000 euro) in the three migration } \\
\text { alternatives; see Appendix, Table A1. }\end{array}$ & $\begin{array}{l}2.151 \text { (alt.0) } \\
2.074 \text { (alt.1) } \\
2.095 \text { (alt.2) }\end{array}$ \\
\hline
\end{tabular}

Notes: All variables measured at the region of origin in 1993 if not otherwise stated. Number of observations: $N=9,221$. Reference category for the educational dummies is primary education. For labour market status (employment, unemployment) it is out of the labour market. Individual's distance to the closest growth-centre region was calculated as follows: first the distance between two regions was calculated by using a distance matrix based on the relative location of the municipalities (Source: Finnish Road Administration), then in each subregion the most populated municipality was chosen to represent the location of the region. 
Table 2. Parameter estimates of the random parameters logit model

\begin{tabular}{|c|c|c|c|c|}
\hline \multirow{3}{*}{$\begin{array}{l}\text { Non-random parameters } \\
\text { Constant }\end{array}$} & \multicolumn{4}{|c|}{ Alternative } \\
\hline & \multicolumn{2}{|c|}{ Periphery migration } & \multicolumn{2}{|c|}{ Growth-centre migration } \\
\hline & 1.094 & $(1.132)$ & -1.903 & $(1.121)$ \\
\hline Age & $-0.403 * *$ & $(0.127)$ & $-0.771^{* *}$ & $(0.149)$ \\
\hline Lower secondary education & -0.582 & $(0.299)$ & $0.903 *$ & $(0.424)$ \\
\hline Upper secondary education & -0.358 & $(0.408)$ & $1.342^{* *}$ & $(0.287)$ \\
\hline Lower upper education & 0.201 & $(0.437)$ & $1.630^{* *}$ & $(0.343)$ \\
\hline Higher upper education & 0.344 & $(0.577)$ & $2.575^{* *}$ & $(0.420)$ \\
\hline Married or cohabiting & 0.274 & $(0.341)$ & 0.544 & $(0.290)$ \\
\hline Spouse is employed & $-0.752 * *$ & $(0.253)$ & $-0.557 *$ & $(0.251)$ \\
\hline \# children under 7 & -0.106 & $(0.177)$ & -0.344 & $(0.185)$ \\
\hline \# children aged 7-18 & -0.139 & $(0.159)$ & $-0.703^{* *}$ & $(0.208)$ \\
\hline Home-owner & $-0.967 * *$ & $(0.208)$ & -0.347 & $(0.188)$ \\
\hline Employed & 0.174 & $(0.315)$ & -0.461 & $(0.283)$ \\
\hline Unemployed & $1.386^{*}$ & $(0.605)$ & 0.426 & $(0.322)$ \\
\hline Work experience & -0.123 & $(0.082)$ & 0.040 & $(0.050)$ \\
\hline Initial earnings & $-0.443^{* *}$ & $(0.172)$ & -0.077 & $(0.150)$ \\
\hline Commuting & $0.936^{* *}$ & $(0.274)$ & $1.780^{* *}$ & $(0.250)$ \\
\hline Regional rate of unemployment & -0.007 & $(0.027)$ & -0.024 & $(0.025)$ \\
\hline Share of service workers & $-0.447 * *$ & $(0.120)$ & -0.181 & $(0.109)$ \\
\hline Living in region of birth & $-0.935^{* *}$ & $(0.195)$ & $-0.744 * *$ & $(0.185)$ \\
\hline Distance to the closest growth-centre & $0.039 * *$ & $(0.014)$ & $0.047^{* *}$ & $(0.015)$ \\
\hline
\end{tabular}

Normally distributed random parameter for expected disposable income:

Mean: 1.463* (0.719); Std. dev: 0.021 (0.942)

Notes: Reference state is staying. First, the estimated parameter is given, followed by the asymptotic standard errors in brackets. See Table 1 for the variable definitions and mean values. Loglikelihood: $-1,155.47$. Number of observations: $N=9,221$. Replications for simulated probabilities (Halton): $500 . *(* *)=$ statistically significant at the $0.05(0.01)$ level. 
Table 3. The estimated impacts and costs of two income policy interventions

\begin{tabular}{|c|c|c|c|}
\hline & $\begin{array}{l}\text { Without policy } \\
\text { intervention }\end{array}$ & $\begin{array}{l}\text { After } 10 \% \text { increase in } \\
\text { expected disposable } \\
\text { income }\end{array}$ & $\begin{array}{l}\text { After } 25 \% \text { increase in } \\
\text { expected disposable } \\
\text { income }\end{array}$ \\
\hline & \multicolumn{3}{|c|}{ Probability of alternative (change, \%) } \\
\hline Staying & 0.9704 & $(0.2 \%)$ & 0.9743 \\
\hline Periphery migration & 0.0138 & $0.0139 \quad(0.7 \%)$ & $0.0140 \quad(1.4 \%)$ \\
\hline \multirow[t]{2}{*}{ Growth-centre migration } & 0.0159 & $0.0140 \quad(-11.9 \%)$ & $0.0117(-26.4 \%)$ \\
\hline & \multicolumn{3}{|c|}{ Calculation of approximate costs } \\
\hline Employed individuals & $26,898^{(1}$ & $26,898^{(2}$ & $26,898^{(2}$ \\
\hline Annual income per individual, euro & $13,453^{(1}$ & $13,453^{(2}$ & $13,453^{(2}$ \\
\hline $\begin{array}{l}\text { Annual disposable income per } \\
\text { individual, euro }\end{array}$ & $9,137^{(1}$ & 10,051 & 11,421 \\
\hline Annual costs per individual, euro & - & 914 & 2,284 \\
\hline Total annual costs, euro & - & $24,584,772$ & $61,435,032$ \\
\hline
\end{tabular}

Notes: Policy interventions are targeted at employed individuals living in the four northern subregions listed in the text. An individual receives the increase in the disposable income, assuming s/he does not move to a growth-centre region. Probabilities are simulated with 500 replications (Halton) using the parameter estimates given in Table 2. The probabilities are calculated as averages over all observations. ${ }^{1)}$ Figures are given for 1999 (Sources: Finnish Tax Administration \& Statistics Finland's Kuntafakta). ${ }^{2)}$ Figure is assumed to be unchanged after the policy. 


\section{NOTES}

1. See Williamson, 1988, LucAs, 1997, and United NATiOns, 1999, for a discussion of urbanization in general.

2. For prior evidence on the impact of expected earnings on migration, see FALARIS, 1987, for Venezuela and Islam and ChOudHuRy, 1990, for Canada. They find a positive and significant impact of expected income gain on migration.

3. This implies that the individual moves $(j=1,2)$ only if the net gain from migration ( $\ln P V_{i j}-\ln P V_{i 0}$ ) is greater than zero and selects that destination region for which $\ln P V_{i j}$ is maximized.

4. Taylor's first-order expansion, $f(\theta) \approx f\left(\theta_{0}\right)+f^{\prime}\left(\theta_{0}\right)\left(\theta-\theta_{0}\right)$, at point $\theta_{0}=0$ is $\ln \left(1-\theta_{i j}\right) \approx \ln (1-0)+\frac{-1}{1-0}\left(\theta_{i j}-0\right)=-\theta_{i j}$, because $D(\ln (1-\theta))=\frac{-1}{1-\theta}, \theta<1$.

5. We approximate the present value of expected disposable income with predicted disposable income just after migration (see Appendix for details).

6. The sample selection correction variables $\lambda_{i j}$ are defined as: $\lambda_{i j}=\phi\left(\Phi^{-1}\left(P_{i j}\right)\right) / P_{i j}$, where $\phi$ is the standard normal density function, $\Phi^{-1}$ is the inverse of the standard normal distribution and $P_{i j}$ is the predicted probability of alternative $j$ computed from a reduced-form multinomial logit model that include all variables in $X_{i}$ and $Z_{i}$ (see equations 5 and 6; and LEE, 1983; FALARIS, 1987).

7. The predicted value can be calculated as: $\ln \hat{W}_{i j}=X_{i} \beta_{j}$. Similarly, $\hat{W}_{i j}=\exp \left(X_{i} \beta_{j}+\sigma_{j}^{2} / 2\right)$, where $\sigma_{j}^{2}$ is the estimated variance of the error term $v_{i j}$ 
in equation (5). The result follows from the expected value properties of lognormal distributions (see, for example, MooD et al., 1974, p. 117).

8. Note that the error term $\varepsilon_{i j}$ is not exactly Gumbel-distributed, since it is a linear function of the Gumbel error term $\left(\xi_{i j}\right)$ and the normal error term $\left(\omega_{i j}\right)$. Fortunately, the assumption is defensible since both distributions have somewhat similar shapes (VIJVERBERG, 1995). A similar assumption has been made previously (LEE, 1983; VIJVERBERG, 1995).

9. Due to "Iron Law of Economics", measurement errors are likely to bias the parameter estimates toward zero (CAMERON and TRIVEDI, 2005).

10. Random parameters logit models can be estimated by maximising a simulated log-likelihood function (see STERN, 1997, for a discussion). In this study, to reduce simulation error, the simulations are based on Halton draws (TRAIN, 2003). A more advanced treatment of the measurement errors would have required the use of panel data (CARroll et al., 1995). Due to data limitations this was left for a further study.

11. We used data from 84 subregions. The subregion of Åland was excluded, as it has many distinctive characteristics (including self-regulation, isolated geographical location and a Swedish-speaking majority). One limitation of the data set is that it does not allow us to use households as the unit of analysis, because we do not know which individuals belong to the same households. However, we do have wide range of household variables, which should control for the dependencies in the migration decision-making. 
12. The regional classification into growth-centre regions and peripheral regions was formed using information on the net migration rates and population figures: a region is classified as a growth-centre region, if it had a positive net in-migration rate and its population was larger than 50,000 inhabitants in 1995. The division is not sensitive to population size.

13. An annual income greater than 1,000 euro was considered positive. The income threshold is necessary in order to obtain meaningful income measures. Selfemployed, retired and foreign-born individuals were excluded from the sample, as the factors determining their incomes are likely to differ from those applicable to the rest of the population. In addition, those who were students in 1995 were excluded from the sample.

14. See the literature on the impact of taxation and the public sector on migration (Islam, 1989; ChARNeY, 1993; Westerlund and WyZAN, 1995; see also equations 1 and 2).

15. Note, however, that the choice of commuting may also reflect high personal costs of migration in the first place (ELIASSON et al., 2003).

16. We, neither, found any significant impact of municipal taxation on the migration propensity of individuals. Hence, highly insignificant and small coefficients were omitted from the final model. This result is expected because differences in taxation are fairly small between regions in Finland and thus inter-regional tax competition seems limited.

17. In practice, income policy interventions could be implemented, for example, through exemptions of some kind from personal income taxation. 